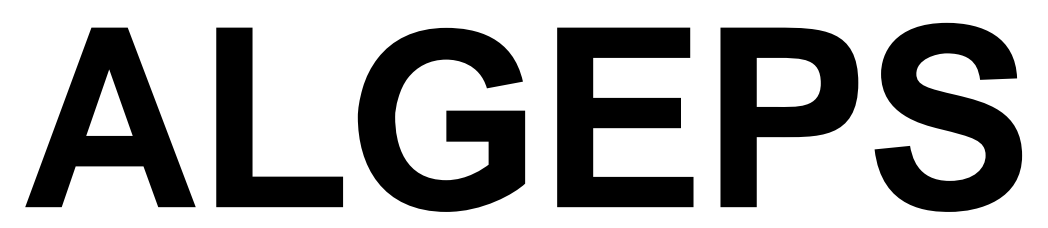

REVISTA DE GEOLOGIA, SÈRIE B no 602 - Setembre del 2012

ISSN $1132-7014$

D.L.B. 28.178 - 92

14 pàgines

\begin{abstract}
RECORREGUT DE RECERCA GEOLÒGICA, GEOAMBIENTAL I MINERALÒGICA PER LES COMARQUES DEL BAIX LLOBREGAT I DE L'ALT PENEDÊS: DES DE GAVÀ A BRUGUERS, BEGUES, OLESA DE BONESVALLS I AVINYONET DEL PENEDÈS
\end{abstract}

Josep M. Mata-Perelló

Aquest recorregut va ésser experimentat amb docents el dia 19 DE GENER DEL 2011 


\title{
RECORREGUT DE RECERCA GEOLÒGICA, GEOAMBIENTAL I MINERALÒGICA PER LES COMARQUES DEL BAIX LLOBREGAT I DE L'ALT PENEDÈS: DES DE GAVÀ A BRUGUERS, BEGUES, OLESA DE BONESVALLS I AVINYONET DEL PENEDÈS / 19a DE GENER DEL 2011
}

\author{
Per Josep M. MATA-PERELLÓ
}

\section{ADVERTIMENTS PREVIS}

Com en altres recorreguts de RECERCA GEOLÒGICA I MINERALÒGICA ..., aquest constarà de diverses parades. Però, sols si es disposa del temps suficient, podrà efectuar-se passant per totes les parades $i$ filloles. En cas contrari, recomanem prescindir de les anomenades PARADES - CONDICIONALS.

Pel que fa als camins per on transitarà el recorregut de l'itinerari, cal dir que en general es trobaran en bones condicions. Tot i així, sempre que sigui possible, recomanem demanar la màxima informació, en relació al estat real dels camins. En cas de trobar-se en males condicions, recomanem fer el desplaçament a peu.

En qualsevol cas, cal tenir sempre una cura molt especial de respecte a la natura, al llarg de tot el recorregut; de l'itinerari.

\section{BREU INTRODUCCIÓ}

El recorregut del present itinerari discorrerà, en la seva totalitat per una sola unitat geològica: pel Sistema Mediterrani (i més concretament, ho farà en bona part per una de les sotsunitats que el constitueixen; concretament, per la Serralada Litoral Catalana; tot i que començarà a la Depressió Litoral i finalitzarà a la Depressió Prelitoral).

Així, el recorregut s'iniciarà a la localitat de Gavà, per on es faran diverses aturades, una d'elles dintre de la Depressió Litoral. Tot seguit s'anirà cap a Bruguers, fent el recorregut per la Serralada Litoral Catalana. Després, el recorregut anirà cap al municipi de Begues i cap a Olesa de Bonesvalls (Oleseta), sense abandonar en cap moment l'esmentada Serralada Prelitoral Catalana. Posteriorment, el recorregut es dirigirà cap al poble d'Avinyonet del Penedès, fent la darrera aturada dintre de la Depressió Prelitoral Catalana.

Per d'altra banda, la quasi totalitat del recorregut s'efectuarà per la comarca del Baix Llobregat (i en bona part pel terme de Gavà i pels de Begues i Olesa de Bonesvalls). Tot i així, el tram final, per Avinyonet del Penedès, ś haurà fet per la comarca de l'Alt Penedès. 


\section{OBJECTIUS FONAMENTALS}

Els objectius fonamentals que es pretenen aconseguir en el recorregut d'aquest itinerari, es poden concretar en els següents aspectes generals:

1.- Observació del Sistema Mediterrani, així com de les diferents sotsunitats que la constitueixen.

2.- Observació de la Depressió Litoral Catalana, pels voltants de Gavà, on s'iniciarà el recorregut de 1'itinerari. Reconeixement dels materials cenozoics (del terciari i del quaternari) que la constitueixen.

3.- Observació de la Serralada Litoral Catalana, per la qual discorrerà la major part del recorregut del present itinerari, entre les poblacions de Bruguers (Gavà) i Olesa de Bonesvalls (ambdues situades al Baix Llobregat). I reconeixement dels materials que la constitueixen:

3A) Observació i descripció dels materials paleozoics (exclusivament del Devonià, del Silurià i de l'Ordovicià), els quals constitueixen la Serralada Litoral Catalana, pels voltants de la població de Bruguers.

3B) Observació i descripció dels materials mesozoics (del Triàsic i del Cretàcic exclusivament), els quals constitueixen la Serralada Litoral Catalana, pels voltants de les poblacions de Bruguers, Begues i Olesa de Bonesvalls.

4.- Observació de la Depressió Prelitoral Catalana, fonamentalment pels voltants d'Avinyonet del Penedès. I alhora, reconeixement dels materials cenozoics (del terciari i del quaternari) que la constitueixen.

5. - Observació de les estructures locals d'aquests materials esmentats al paràgraf anterior, al llarg del recorregut de l'itinerari. I alhora, si s'escau, dels contactes entre la Depressió Litoral Catalana i la Serralada Llitoral Catalana. I entre aquesta darrera i la Depressió Prelitoral Catalana.

6.- Observació i reconeixement de diverses mineralitzacions situades a diferents indrets del recorregut de l'itinerari. En concret de:

6A) de les mineralitzacions sedimentàries de fosfats, que trobarem entre els materials paleozoics de la Serralada Litoral Catalana, per les immediacions de les poblacions de Gavà i de Bruguers (al Baix Llobregat).

$6 \mathrm{~B})$ de les mineralitzacions sedimentàries de Fe, que trobarem entre els materials paleozoics de la Serralada Litoral Catalana, per les immediacions de les poblacions de Gavà i de Bruguers (al Baix Llobregat).

6C) si s'escau, de les mineralitzacions estratiformes de Pb-Zn, relacionades amb nivells de karstificació, situades entre les calcaries del Muschelkalk Inferior. Les trobaríem a la Rectoria (Begues)

7.- Observació, si s'escau, i comentari de diverses explotacions mineres, antigues i actuals, situades al recorregut de l'itinerari,

8.- Interpretació dels impactes mediambientals provocats per les explotacions mineres sobre el Medi Natural i sobre el Medi Ambient. I en tot cas de les restauracions dutes a terme per tal de corregir els impactes. 
9.- Observació de l'important Patrimoni Miner relacionat amb les explotacions mineres, que anirem trobant al llarg del recorregut de l'itinerari..

\section{ANTECEDENTS BIBLIOGRÀFICS}

Pel que fa al recorregut del present itinerari, existeixen alguns antecedents parcials, de tipus bibliogràfic referent a diferents parts del recorregut del mateix; es tracta de MATAPERELLÓ (1996a, 1996b, 1997, 1998, 1999a,1999b, 2001a, 2002b, 2004, 2008a, 2008b i 2010). I també a MATA LLEONART et altri (2001). Trets d'aquests antecedents, no en tenim coneixement de cap altres. Tot i així, farem esment d'un important treball de SOLE SABARÍS (1964), on es descriu un recorregut molt proper al que ara presentem, dintre d'un conjunt de recorreguts pels voltants de Barcelona. Tot o així, els antecedents d'itineraris són pràcticament inexistents pel terme de Begues i de Olesa de Bonesvalls, a excepció dels nostres darrers esmentats.

Pel que fa a la descripció de les mineralitzacions de les comarques per les quals discorre l'itinerari, cal parlar d'uns altres treballs nostres, de MATA-PERELLÓ (1988 i 1991), el primer relatiu al conjunt de les mineralitzacions catalanes en general, distribuïdes per comarques, $\mathrm{i}$ esmenant-se les corresponents al. També pot fer-se esment del treball comarcal de MATAPERELLÓ (1988), en un treball relatiu a la comarca del Baix Llobregat.

I, finalment, pel que fa a l'estructura geològica de la zona per la qual discorre l'itinerari, farem esment dels treballs de: GUIMERÀ et altri (1982) i de RIBA et altri (1976). Tanmateix, farem esment de les fulles de IGME (1976a i 1976b) relativa a la zona per on discorre el recorregut del present itinerari.

Tots aquests treballs referenciats, i d'altres, figuren esmentats per ordre alfabètic a l'apartat dedicat a la BIBLIOGRAFIA.

\section{RECORREGUT DE L'ITINERARI}

L'inici del recorregut de l'itinerari, es realitzarà ben a la població de Gavà, per on realitzaran les primeres aturades del recorregut, dintre de la comarca del Baix Llobregat. Tot seguit, a través de la carretera BV - 2041, el recorregut es dirigirà cap a Bruguers, per on es faran diverses aturades, especialment pels voltants de l'església Romànica.

Posteriorment, seguint per la mateixa carretera local, el recorregut es dirigirà cap a les immediacions de Begues, per on es faran noves aturades. Tot seguit, es dirigirà cap a Olesa de Bonesvalls. En aquesta població es faran noves aturades.

Posteriorment, el recorregut de l'itinerari es dirigirà cap a la població d'Avinyonet del Penedès, deixant la comarca del Baix Llobregat i entrant ara a la de l'Alt Penedès. Aquest darrer tram es farà a través de la carretera BV - 2411. En aquesta darrera població, finalitzarà el recorregut. 


\section{DESCRIPCIÓ DE L'ITINERARI}

Com ja es habitual, s'estructurarà en una sèrie d'estacions (parades o aturades), en les qual es faran descripcions geològiques o mineralògiques, si s'escau. En cada cas sindicarà el número del mapa topogràfic a escala 1:50.000 on es troba l'indret.

En aquest cas, el recorregut de l'itinerari passarà exclusivament per dos dels fulls. Concretament pel 420 (o d'Hospitalet de Llobregat) i per 448 (o de Gavà), de l'Instituto Geográfico y Catastral", realitzat a l'escala de 1:50.000. Així doncs, la relació i descripció de les aturades que composen aquest itinerari, és la següent:

PARADA 1. FORN DE CALÇ DE LA CARRETERA DE LA SENTIU, (terme municipal de Gavà, comarca del Baix Llobregat). (Full 448).

El recorregut de l'itinerari l'haurem començat a la població de Gavà. Aquí, ens caldrà agafar la carretera que es dirigeix cap a la Sentiu. Poc després d'agafar-la farem la primera aturada, a uns $2 \mathrm{Km}$ de l'inici del centre de Gavà.

En bona part aquest recorregut l'haurem anat circulant per entre els materials cenozoics de la Depressió Litoral Catalana (amb afloraments de terrenys del Terciari Superior, del Pliocè i del Quaternari). Tot i així, per on ara som, haurem trobat la Serralada Litoral Catalana, per on es troba part de Gavà i on es troba aquest indret. Així, pels voltants d'on som ara es veuen sediments rogencs del Buntsandsteim, per arreu; així com dels trams carbonatats del Muschelkalk Inferior. Precisament, aquests darrers han estat explotats en aquest lloc, en una pedrera que ara s'està tapant amb runes.

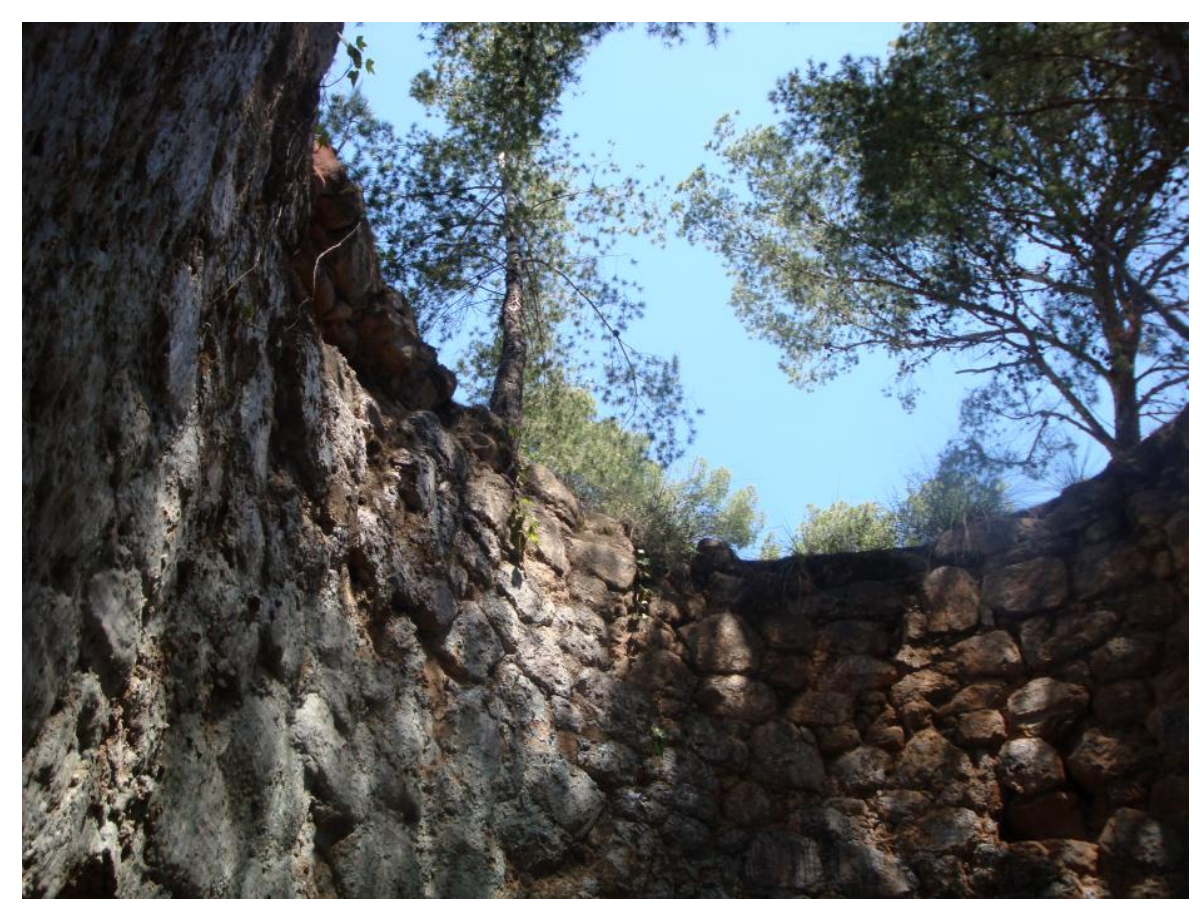

FOTOGRAFIA 1. Un aspecte de la part alta del forn 
Per sota de la pedrera hi ha unes tremuges i un antic forn de calç. Aquest es troba en bon estat de conservació i forma part del Patrimoni Miner, tant de Gavà com del de la comarca del Baix Llobregat (FOTOGRAFIA 1). Per veure aquest forn de calc, cal demanar la corresponent autorització.

PARADA 2. LES FERRERES, (terme municipal de Gavà, comarca del Baix Llobregat). (Full 448).

Després de realitzar la parada anterior, cal retornar cap a les immediacions de Gavà, fins trobar en una cruilla la carretera BV-2041, per on seguirem ara. Aquesta carretera és en realitat una variant de circumval-lació. Tot i així, en arribar a la darrera sortida de la població ens caldrà tornar a entrar-hi per dalt, per tal d'anar cap al paratge de les Ferreres, on farem la present aturada, després de recórrer uns $3 \mathrm{Km}$, des de l'anterior.

En aquest recorregut, hem circulat sempre dintre de la Serralada Litoral Catalana, on ara ens trobem situats. Així, en aquest indret es troben importants afloraments dels materials del Silurià i del Devonià. Aquests es troben fonamentalment constituïts per trams de materials esquistos amb trams de carbonats.

En aquest lloc es fan clarament paleses unes mineralitzacions inicialment estratiformes (parcialment remobilitzades, i adquirint un cert aspecte filonià). Els minerals presents, són entre altres: GOETHITA (limonítica), HEMATITES, TURQUESA i VARISCITA, entre altres minerals.

Per d'altra banda, des d'aquest indret, mirant cap a Gavà es pot veure el contrast entre el relleu de la Serralada Litoral Catalana i el de la Depressió Litoral Catalana (amb el Delta del Llobregat).

PARADA 3. MINES DE FERRO DE ROCABRUNA, (Bruguers, terme municipal de Gavà, comarca del Baix Llobregat). (Full 448).

Des de la parada anterior, cal arribar a la carretera local BV-2041, per tal d'anar cap a la propera localitat de Bruguers. Poc abans d'arribar-hi, es trobarà per la dreta de la carretera el camí que condueix cap al paratge de Rocabruna, on efectuarem la present aturada. El recorregut, des de la carretera fins a l'indret de l'aturada el farem a peu (menys de $1 \mathrm{Km}$ ). Per tal d'arribar aquí, des de la parada anterior, recorrerem uns $5 \mathrm{Km}$.

Tot aquest recorregut, s'haurà efectuat entre els afloraments paleozoics de la Serralada Litoral Catalana. Tot i així, en arribar a les immediacions de Bruguers es fan clarament palesos uns afloraments dels trams gresencs del Triàsic Inferior. Tot i així, en el camí de descens cap a les Mines de Rocabruna, es fan clarament palesos els afloraments dels materials paleozoics, del Devonià (amb trams carbonatats), del Silurià (amb pissarres fosques) i de l'Ordovicià (també amb pissarres). Els dos primers trams paleozoics són els que afloren pels voltants de les antigues explotacions mineres.

Per d'altra banda, en arribar a l'indret de la parada es fan clarament paleses unes 
mineralitzacions sedimentàries. Aquestes es troben entre els afloraments paleozoics acabats d'esmentar. Entre els minerals presents, es troben els següents: GOETHITA (limonítica i terrosa), i HEMATITES (terròs). Tots dos van ésser intentats d'explotar a unes antigues mines de ferro. Tot i així, predomina la roca LIMONITA (amb presencia majoritària de l'esmentada GOETHITA; i també de LEPIDOCROCITA i SIDEROGEL, molt més minoritaris).

En aquest lloc hi ha un interessant conjunt $d^{\prime}$ instal-lacions mineres, les quals formen part del nostre patrimoni miner

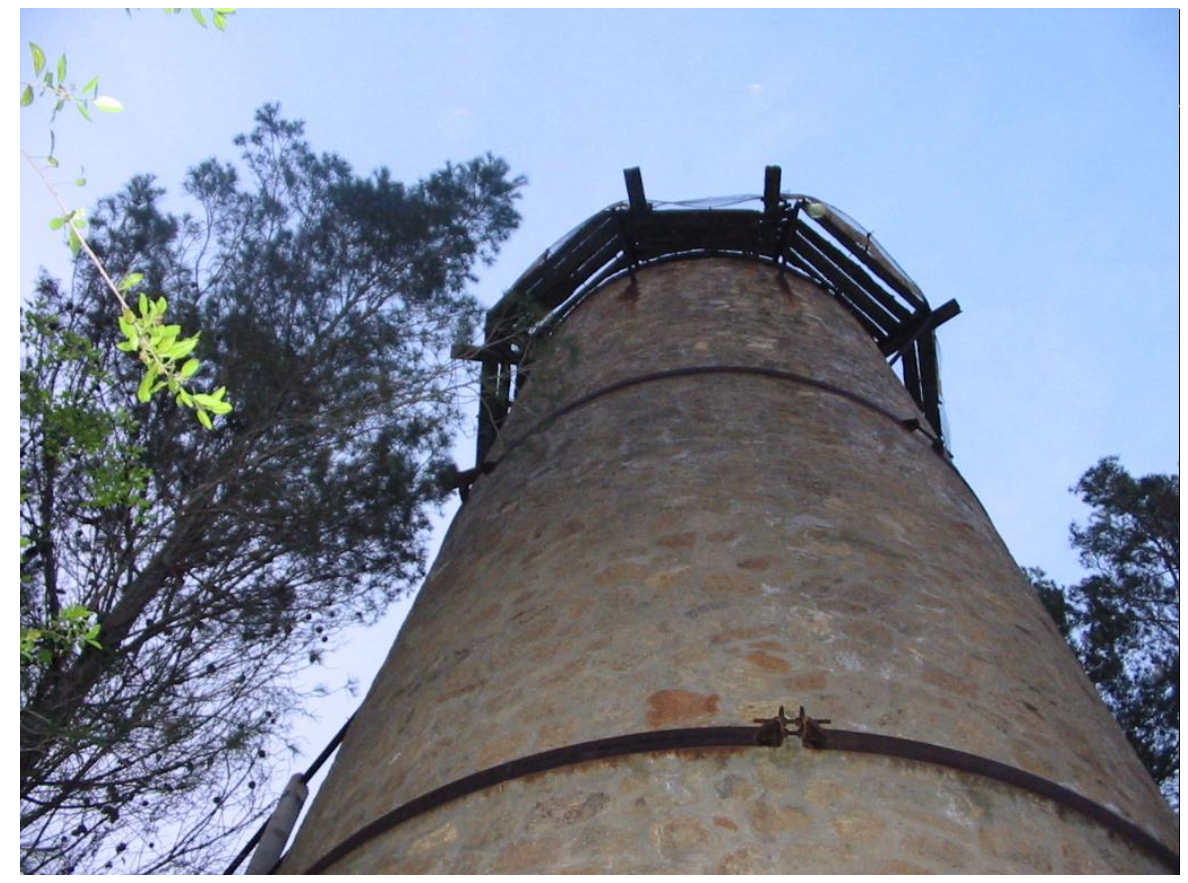

FOTOGRAFIA 2. Restes de les tolves de les mines de ferro.

Per d'altra banda, a més a més dels minerals anteriorment esmentats, també se'n troben altres com PIROLUSITA, CALCITA, CALCIOFERRITA i TINTICITA, entre altres molts més minerals.

PARADA 4. ERMITA DE BRUGUERS, (Bruguers, terme municipal de Gavà, comarca del Baix Llobregat). (Full 448).

Després de fer la parada anterior, cal retornar a la carretera. En arribar a ella, ens caldrà seguir cap a les immediacions de Bruguers. Aquí realitzarem la propera aturada d'aquest itinerari, a uns 1'5 Km de la parada anterior.

En aquest recorregut, hem trobat inicialment els materials paleozoics esmentats a la parada anterior. Tot i així, en arribar a les immediacions de la parada, hem començat a trobar els afloraments dels terrenys rogencs del Buntsandstein, del Triàsic Inferior. Precisament, aquests són els materials que apareixen per arreu a l'indret de l'aturada. I tanmateix, d'ells procedeixen els materials utilitzats a diverses construccions de Bruguers. Així, en aquest indret es pot fer una bona observació dels materials emprats en la construcció de l'església. Per d'altra banda, és un bon exemple de l'arquitectura romànica. 
Així, en aquest lloc es poden veure aquests materials per sobre de 1’Ermita. Aquí. Aquests materials rogencs presenten unes interessants estructures alveolars, desenvolupats per l'acció conjunta de l'aigua i del vent.

És molt interessant fer un recorregut a peu, des de 1'Ermita de la Mare de Deu de Bruguers, fins al Castell de l'Eranprunyà. En aquest recorregut es pot fer un bon tall dels materials del Buntsandstein. Alhora es pot arribar fins al Pont Natural de Bruguers.

\section{PARADA 5 - CONDICIONAL. EL PONT NATURAL DE BRUGUERS, (Bruguers, terme municipal de Gavà, comarca del Baix Llobregat). (Full 448).}

Després de realitzar l'aturada anterior, cal fer un breu recorregut a peu, d'uns $250 \mathrm{~m}$, aproximadament, pel camí que es dirigeix cap al Castell de l'Aranprunyà. En aquests trajecte cal fer una nova aturada.

En aquest breu recorregut, hem anat trobant afloraments dels materials triàsics del Buntsandstein. Aquests es troben constituïts aquí per gresos i microconglomerats, de composició eminentment silícica.

Sobre aquests materials s'ha realitzat una intensa erosió eòlica (i de l'aigua, al mateix temps). Aquesta erosió ha contribuït a la formació de tafònits (alvèols), alguns dels quals són veritablement espectaculars.

PARADA 6. COLL DE BRUGUERS, (Bruguers, terme municipal de Gavà, comarca del Baix Llobregat). (Full 448).

Després de fer l'aturada anterior, ens cal seguir el recorregut per la carretera local que es dirigeix a Begues i cap a Olesa de Bonesvalls (la BV-2041). Poc abans d'arribar al Barri de la Rectoria, del municipi del Begues, trobarem un trencall per l'esquerra, que haurem d'agafar. Poc després d'agafar-lo farem una nova aturada, a uns $3 \mathrm{Km}$ de l'anteriorment realitzada. En trobar aquest trencall, ens caldrà anar un tros del recorregut a peu, amb la intenció d'arribar al Coll de Begues i si s'escau fins a la base del Turó de la Desfeta.

En aquest recorregut, haurem trobat afloraments dels materials rogencs del Buntsandstein. Aquests són els que hi ha a l'indret de l'aturada. Tot i així, per sobre d'aquests es fan molt palesos els materials carbonatats del Triàsic Mig, concretament del Muschelkalk Inferior, amb trams de calcaries i de dolomies.

Així, en aquest recorregut des de Bruguers fins on sara som, haurem vist uns interessants afloraments dels materials rogencs del Buntsandstein (del Triàsic Inferior) amb trams de gresos i de conglomerats quarsífers, de vegades molt potents. Per d'altra banda, entre aquests materials, haurem vist molts bons exemples d'erosió alveolar, fins i tot amb la formació de coves i de ponts naturals. Aquests materials són els que hi ha a l'indret de l'aturada, per sota dels materials carbonatats abans esmentats.

Per d'altra banda, des d'aquest indret es pot gaudir d'un bon lloc d'observació de la Depressió Litoral així com del Delta del Llobregat. 


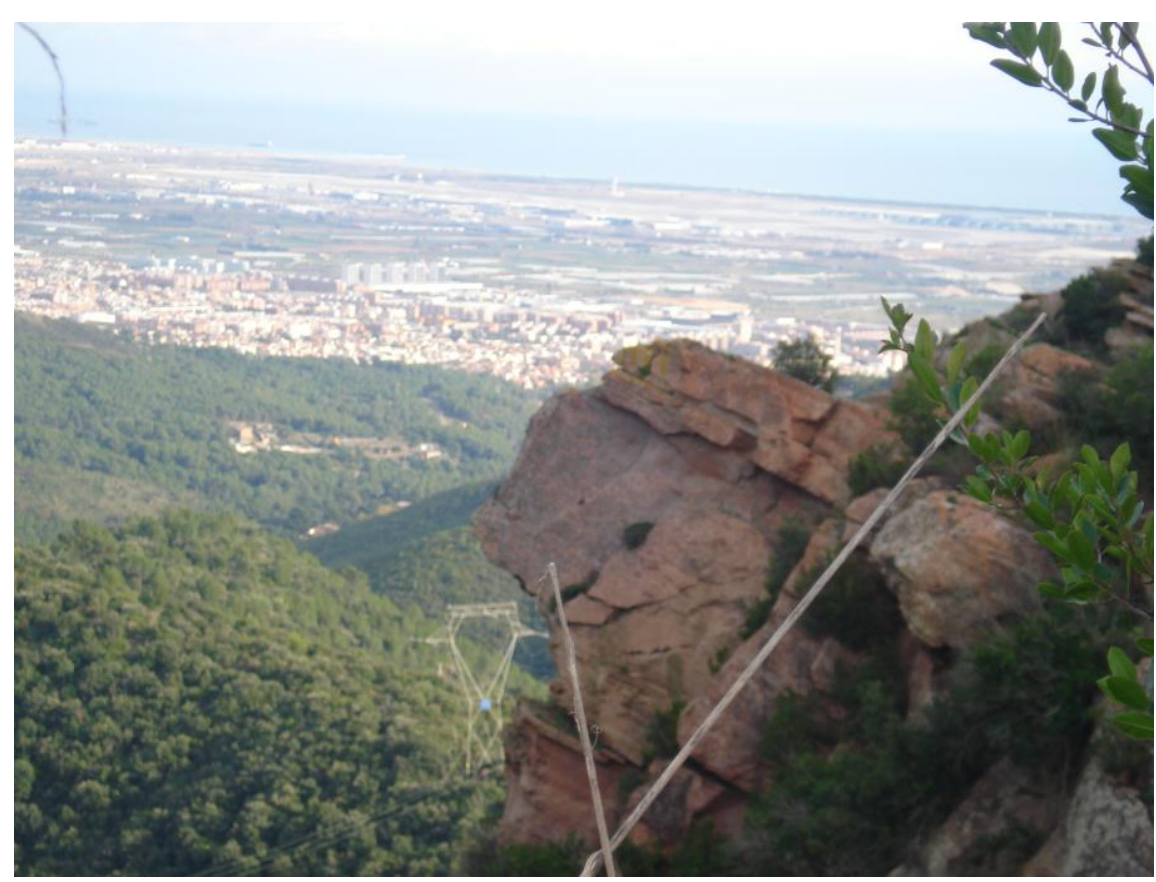

FOTOGRAFIA 3. Un aspecte dels materials del Buntsandstein.

Al fons la Depressió Litoral i el Delta del Llobregat

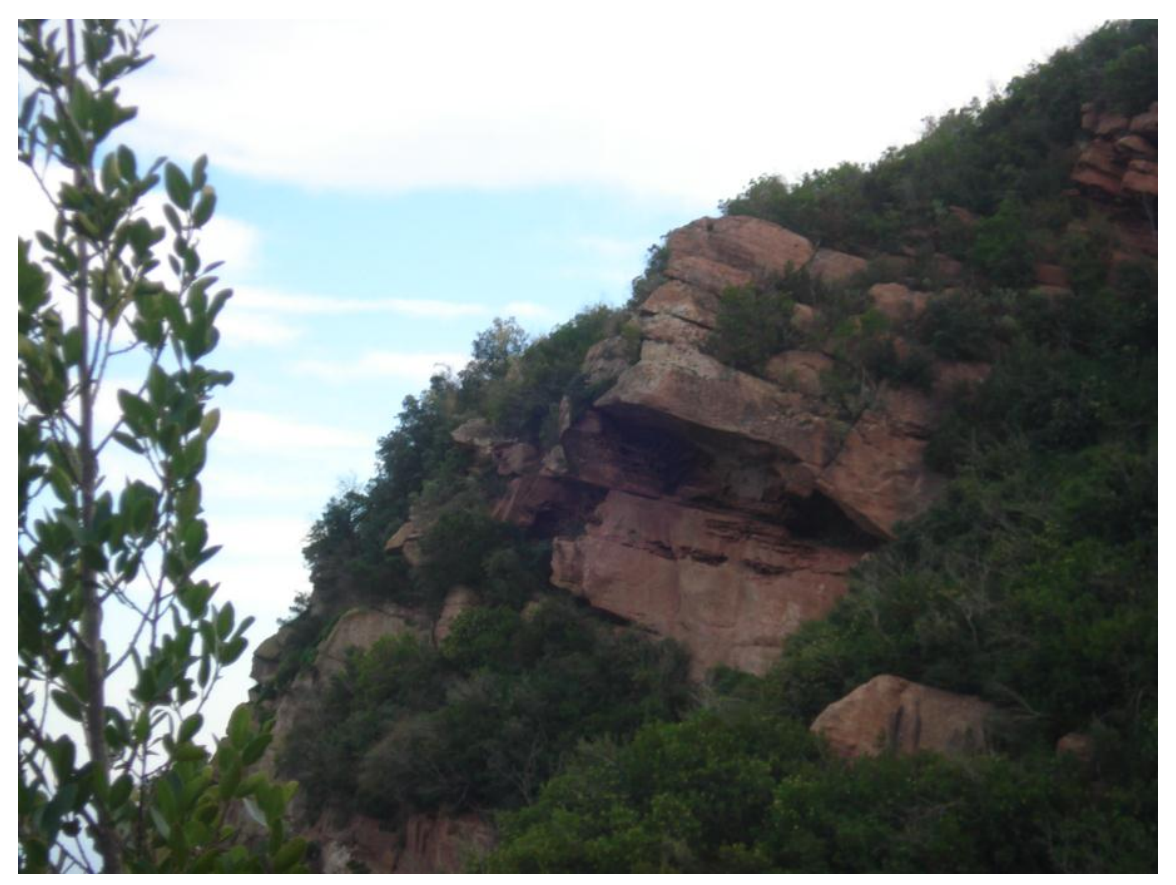

FOTOGRAFIA 4. Un altre aspecte dels materials del Buntsandstein.

PARADA 7. PLANA DE LA RECTORIA, (la Rectoria, terme municipal de Begues, comarca del Baix Llobregat). (Full 448).

Després de realitzar la parada anterior, cal fer un nou recorregut per la carretera que anem seguint des de Bruguers, , per tal d'arribar fins a la Rectoria. Aquí realitzarem una nova aturada, després de recórrer poc menys de $1 \mathrm{Km}$. 
En aquest recorregut, hem anat trobant inicialment afloraments del materials rogencs del Triàsic Inferior (del Buntsandstein), amb trams de gresos i de calcolutites rogenques. Més endavant, haurem trobat afloraments dels nivells carbonatats triàsics del Muschelkalk Inferior (amb calcaries i dolomies). Així, haurem anat sempre ascendent (topogràficament com estratigràficament). Després, per sobre d'aquests haurem trobat afloraments dels trams de gresos i calcolutites rogenques del Muschelkalk Mig.

Prop de la Rectoria, es fan paleses unes morfologies depressives entre els materials acabats d'esmentar. Aquestes depressions corresponen a dolines, uvales i poljés, desenvolupades a partir dels karts que afecta als nivells carbonatats del Muschelkalk Inferior.

PARADA 8 - CONDICIONAL. MINETA DE PLOM DE L'ALZINA, (la Rectoria, terme municipal de Begues, comarca del Baix Llobregat). (Full 448).

Després de fer la parada anterior, cal fer un nou i petit recorregut per la carretera BV-2041. Després caldrà agafar un cami-carreter que se'n va cap a l'Alzina. Des d'aquí caldrà agafar el corriol que baixa cap a les antigues Mines de l’Alzina. Aquí farem una nova aturada, després de recórrer uns 1'2 Km des de la parada anterior.

En aquest recorregut, hem tallat inicialment els materials esmentats a la parada anterior. Després hem tornat a trobar els materials carbonatats del Muschelkalk Inferior, en descendre cap a l'indret de la mina.

En arribar a l'indret de l'aturada, s fan paleses unes interessants mineralitzacions de $\mathrm{Pb}-\mathrm{Zn}$. Es tracta d'unes mineralitzacions estratiformes de $\mathrm{Pb}-\mathrm{Zn}$ associades a nivells de karstificació, que es troben entre els nivells carbonatats del Muschelkalk Inferior.

Entre els minerals presents, cal fer esment de l'ESFALERITA i la GALENA (molt més abundant que l'anterior). Amb ells es troben també altres minerals com els següents: GOETHITA (terrosa i limonítica), CALCITA, CERUSSITA i SMITHSONITA. Els dos darrers s'han format a partir de l'alteració de l'esfalerita i de la galena. Pel que fa a les mines, cal dir que queda una galeria, bastant assequible, però força estreta.

\section{PARADA 9. TRENCALL DE LES IMMEDIACIONS DE LA GASOLINERA DE BEGUES - PARC, (la Barceloneta, terme municipal de Begues, comarca del Baix Llobregat). (Full 448).}

Després de fer la parada anterior, cal retornar a la carretera, per tal de seguir cap a la propera població de Begues. Després de sobrepassar-la, caldrà seguir cap a Olesa de Bonesvalls, passant després pel barri de la Barceloneta. Tot i així, en passar per les immediacions de la Gasolinera de Begues - Parc es pot fer una nova aturada, a uns $4 \mathrm{Km}$ de la anterior.

En aquest recorregut, hem anat trobant afloraments dels materials mesozoics del Muschelkalk Mig, amb trams de gresos i calcolutites rogenques. Aquests materials apareixen a l'indret on es troba la gasolinera 


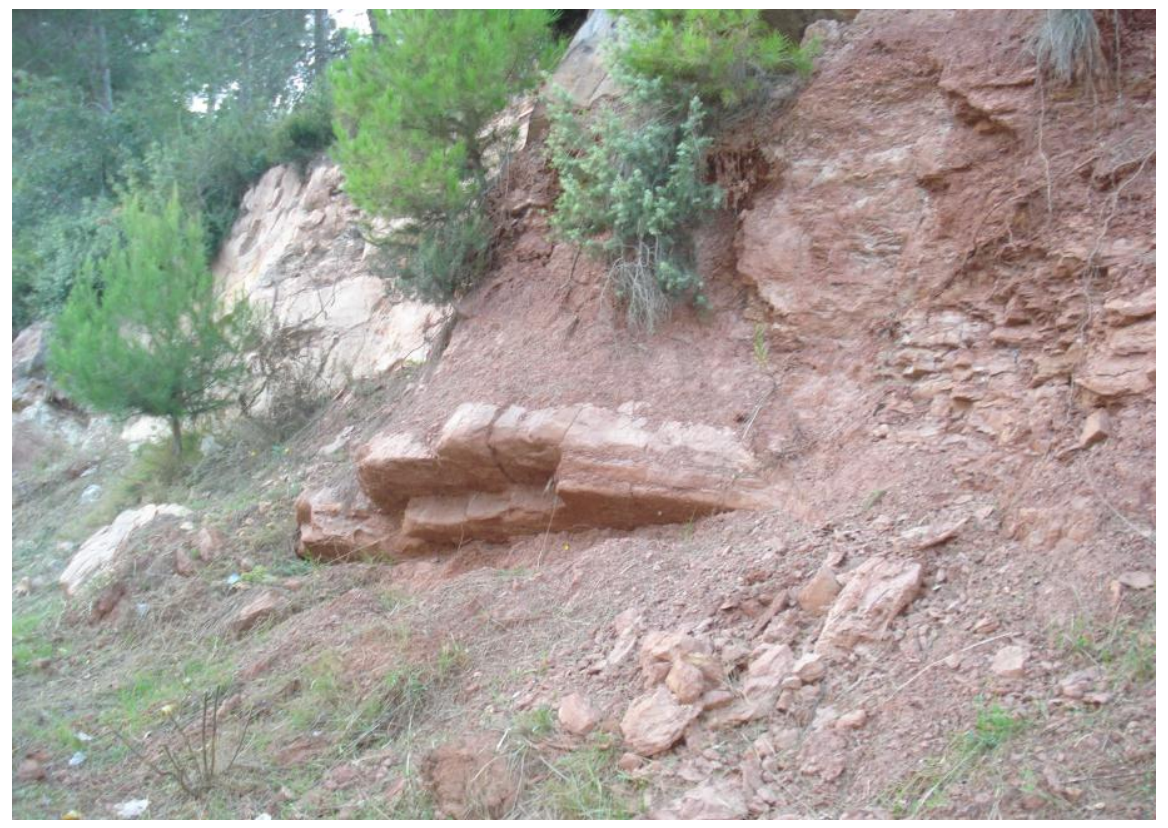

FOTOGRAFIA 5. Afloraments dels nivells rogencs del Muschelkalk Mig

PARADA 10. PEDRERES DEL MONCAU I DE LA PENYA DEL MIGDIA, (la Barceloneta, terme de Begues, comarca del Baix Llobregat). (Full 420).

Desprès de fer l'aturada anterior, cal fer un breu recorregut per la carretera que ara es dirigeix cap a Olesa de Bonesvalls. Tot i així, si s'escau, a menys de $1 \mathrm{Km}$ de la parada anterior, es pot tornar a fer-ho.

En aquest recorregut, hem trobat els nivells de gresos i calcolutites rogenques ja esmentades a la parada anterior, les quals pertanyen al Muschelkalk Mig. Més endavant, per sobre dels materials anteriors, prop d'aquesta lloc on ara som (per sota del Montcau i de la Penya del Migdia) apareixen uns nivells carbonatats (amb calcàries i amb dolomies), situats per sobre dels anteriors. Aquests pertanyen al Muschelkalk Superior. Poc després, apareixen uns altres nivells carbonatats, més potents. Aquests són els que apareixen a l'indret de l'aturada (situada per sota dels relleus del Montcau i de la Penys del Migdia, que queden lleugerament al Nord d'on ara som). Aquests materials es troben en contacte amb els anteriors per una fractura de direcció clarament "catalana" $S E-N W$.

Precisament, aquests darrers materials carbonatats han estat explotats en unes pedreres. Aquestes es troben situades a la dreta de la carretera, tot anant cap a Olesa de Bonesvalls. Aquests materials aquí explotats, són triturats com a àrids lleugers, per tal d'ésser emprats per a la fabricació de formigons. Tot i així, una de les dues pedreres es troba actualment aturada.

\section{PARADA 11. PEDRERA DE CALCÀRIES D’OLESA DE BONESVALLS, (terme d'Olesa de Bonesvalls, comarca del Baix Llobregat). (Full 448).}

Després de fer la parada anterior, cal retornar a la carretera, per tal de seguir cap a la 
propera població d'Olesa de Bonesvalls. Tot i així, a uns $4 \mathrm{Km}$ abans d'arribar al poble, ens caldrà fer una nova aturada.

En aquest recorregut, hem anat trobant afloraments dels materials carbonatats esmentat a la parada anterior. Es tracta dels nivells de calcàries del Cretàcic. Aquestes calcàries han estat explotades a diferents indrets, molt propers d'on ara ens trobem situats.

Així, en aquest indret es pot gaudir de l'observació duna cantera de calcàries, adreçades a l'obtenció de cal viva. En aquesta cantera es poden observar intercalacions de trams cal-lulolítics. Tanmateix es poden veure diverses falles, les quals es fan ressò gràcies a la presència dels miralls de falla.

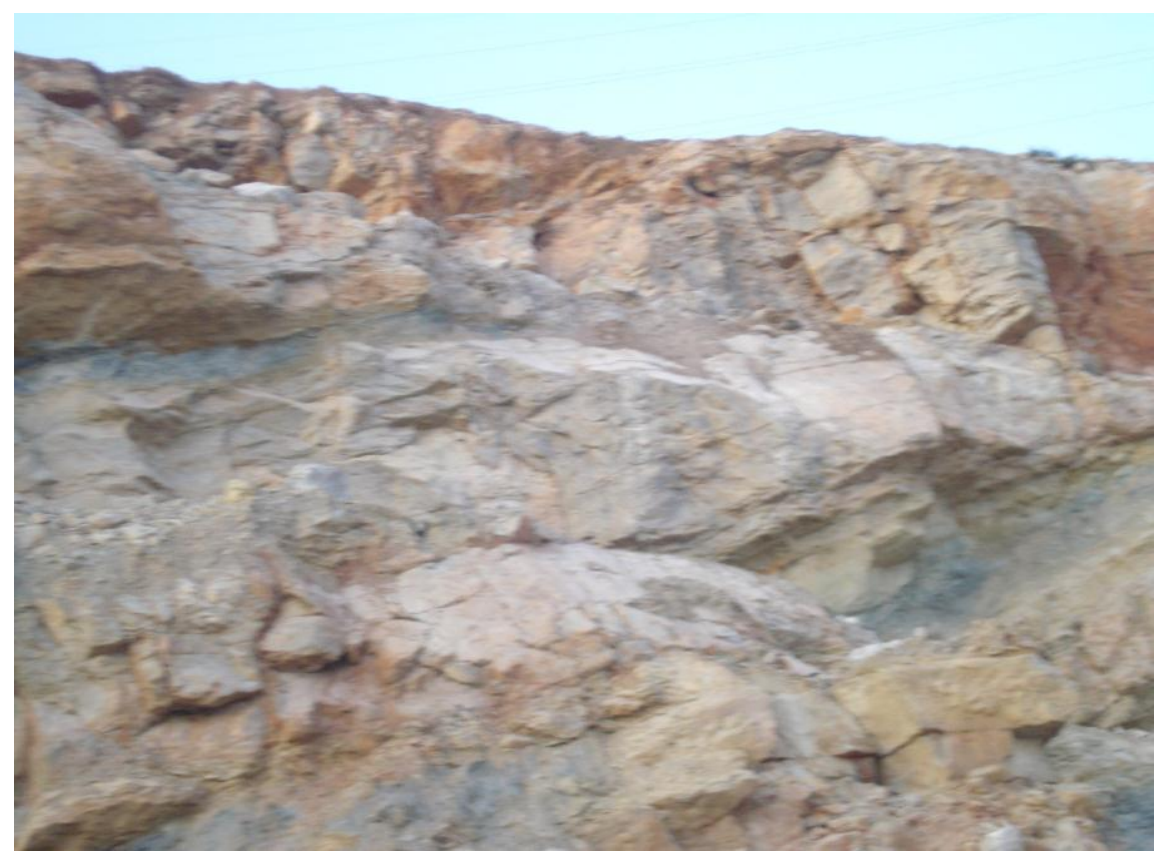

FOTOGRAFIES 6. Mirall de falla d'una de les fractures

Per, d'altra banda, des d'aquest indret es pot fer una bona observació dels sistemes d'explotació de la cantera.

\section{PARADA 12. FORNS DE CALÇ DE LA CANTERA D’OLESA DE BONESVALLS, (terme municipal d'Olesa de Bonesvalls, comarca del Baix Llobregat). (Full 448).}

Després de fer la parada anterior, cal baixar cap a l'indret on es troben els forns on es tractada la calcaria explotada. Per tal d'arribar fins aquest indret, haurem de recórrer uns 0`3 Km, aproximadament.

En aquest recorregut. hem continuat veient explotacions de la cantera de calcàries, on són explotats aquests materials carbonatats. Fins i tot, cap a la part més oriental de la pedrera, haurem vist una interessant falla que talla els materials explotats. 
PARADA 13. ENTRADA A AVINYONET DEL PENEDÈS, (terme municipal d'Avinyonet del Penedès, comarca de l'Alt Penedès). (Full 420).

Després de fer la parada anterior, cal continuar per la carretera BV - 2041, amb la finalitat d'arribar fins a Olesa de Bonesvalls (Oleseta). Després, en arribar a aquesta població, ens caldrà continuar cap a ponent per la carretera BV - 2411, la qual es dirigeix cap al poble d'Avinyonet del Penedès. En arribar-hi, ens caldrà fer una nova aturada, després de recórrer uns $10 \mathrm{Km}$ des de la parada anterior. En aquest recorregut, hem passat de la comarca del Baix Llobregat a la de l'Alt Penedès, on ara som.

En aquest recorregut, hem anat trobant afloraments dels materials mesozoics que formen part de la Serralada Litoral Catalana, per on hem estat circulant dins ara. En bona part, aquests materials pertanyen al Cretàcic.

Tot i així, en arribar a Avinyonet del Penedès, haurem passat de la Serralada Litoral Catalana a la Depressió Prelitoral Catalana, on ara estem situats. Així, per arreu es poden veure materials detrítics quaternaris, els quals cobreixen als terrenys terciaris del Miocè, que reblen l'esmentada Depressió Prelitoral Catalana.

\section{EN AQUEST INDRET FINALITZA EL RECORREGUT}

\section{REFERÈNCIES BIBLIOGRÀFIQUES}

GUIMERÀ, J. ET ALTRI (1992).- Geologia (II), Història Natural dels Països Catalans, vol.2, 547 p.. Enciclopèdia Catalana, S.A. Barcelona

IGME (1976A).- Explicación del mapa geológioc de España, a escala 1:50.000 (2a sèrie). Hoja n' 420 (Hospitalet de Llobregat). Instituto Tecnologico i Geminero de España. Ministerio de Indústria. Madrid

IGME (1976B).- Explicación del mapa geológioc de España, a escala 1:50.000 (2a sèrie). Hoja n' 448 (Gavá). Instituto Tecnologico i Geminero de España. Ministerio de Indústria. Madrid

MATA LLEONART, R; RUBIO MARTÍNEZ, J. I MATA-PERELLÓ, J.M. (2001).- Recorr. de recerca geològica per Martorell, Castellví de Rosanes i Gelida (Baix Llobregat i Alt Penedès). Serralada Prelitoral Catalana i Depressió del Vallès - Penedès. 12 p. Manresa

MATA-PERELLÓ, J.M. (1985).- Els minerals de la regió de Barcelona. Pub. Museu de Geologia "Valentí Masachs", Col Informe no 3, 210 pag. Nanresa

MATA-PERELLÓ, J.M. (1988).- Inventari mineralògic del Vallès Occidental, revista Xaragall, $\mathrm{n}^{\circ} 22$, 26 pàgines. Manresa

MATA-PERELLÓ, J.M. (1991).- Els minerals de Catalunya. Arxius de la Secció de Ciències, t. XCIII, 442 pag. Institut d’Estudis Catalans. Barcelona

MATA-PERELLÓ, J.M. (1996A).- Recerca geològica i mineralògica per les comarques del Baix Llobregat i del Vallès Occidental: des de Castellbisbal a Sant Andreu de la Barca i a Martorell, Inèdit, 
14 pàg. Manresa

MATA-PERELLÓ, J.M. (1997).- Recerca geològica i mineralògica per les comarques del Baix Llobregat i del Vallès Occidental: des de Castellbisbal a Martorell i a Esparreguera. Inèdit, 12 pàgines. Manresa

MATA-PERELLÓ, J.M. (1998).- Recerca geològica i mineralògica per les comarques del Baix Llobregat i d’Anoía: des de Martorell a Masquefa i a Piera. Inèdit, 12 pàgines. Manresa

MATA-PERELLÓ, J.M. (1999A).- Recerca geològica i mineralògica per les comarques del Baix Llobregat i del Vallès Occidental: des de Terrassa i Castellbisbal a Sant Andreu de la Barca; i des de Martorell a Olesa de Montserrat i a la Colònia Sedó. Xaragall, sèrie b, nº 117, pp. 15. Manresa

MATA-PERELLÓ, J.M. (1999B).- Recerca geològica i mineralògica per les comarques del Baix Llobregat, Vallès Occidental i Barcelonès: des de Sant Cugat del Vallès a Santa Creu d'Olorde i a Gavà. Xaragall, sèrie $b, \mathrm{n}^{\circ} 122$, pp. 13. Manresa

MATA-PERELLÓ, J.M. (2001A).- Recorregut de recerca geològica i mineralògica per les comarques del Baix Llobregat i del Vallès Occidental: des de Terrassa i Castellbisbal a Sant Cugat del Vallès i al Papiol, i des de Martorell a Olesa de Montserrat i a Esparreguera. Algeps, sèrie b, no 159, 14 pag. Manresa

MATA-PERELLÓ, J.M. (2001B).- Recorregut de recerca geològica i minera pel Baix Llobregat: des de Gavà a Bruguers i a Begues. Inèdit, 10 pag. Manresa

MATA-PERELLÓ, J.M. (2002).- Recorregut de recerca geològica i mineralògica per les comarques del Baix Llobregat, del Vallès Occidental i del Bages: des de Martorell i Olesa de Montserrat a Castellbell. Algeps, sèrie $\mathrm{b}, \mathrm{n}^{\circ} 160,12$ pag. Manresa

MATA-PERELLÓ, J.M. (2008A).- Recorregut de recerca geològica, geoambiental i mineralògica per la comarca del Baix Llobregat: des de Gavà a Rocabruna, Bruguers i a Begues. Inèdit. 8 pag. Manresa

MATA-PERELLÓ, J.M. (2008B).- Recorregut de recerca geològica, geoambiental i mineralògica per la comarca del Baix Llobregat: des de Bruguers a Begues i a Olesa de Bonesvalls. Inèdit. 10 pag. Manresa

MATA-PERELLÓ, J.M. (2009).- Recorregut de recerca geològica, geoambiental i mineralògica per la comarca del Baix Llobregat: des de Bruguers a Begues i a Olesa de Bonesvalls. Inèdit. 10 pag. Manresa

MATA-PERELLÓ, J.M. (2010).- Recorregut de recerca geològica, geoambiental i mineralògica per la comarca del Baix Llobregat: des de Castellví de Rosanes i Martorell cap a Sant Andreu de la Barca i Bruguers. Inèdit. 8 pag. Manresa

MATA-PERELLÓ, J.M. I FALGUERA TORRES, S. (2004).- Recorregut de recerca geològica, geoambiental i mineralògica per les comarques del Baix Llobregat i del Vallès Occidental: des del Papiol a Castellbisbal i des de Martorell a Gavà. Inèdit. 13 pag. Manresa

RIBA, O. ET ALTRI (1976).- Geografia física dels Països Catalans, Edit. Ketres, 254 pàgines. Barcelona

SOLÉ SABARÍS, L. (1964).- Geologia de los alrededores de Barcelona. Colección la "Nueva Geografia", Minist. de Educ. Nacional. 135 pag. Barcelona 